\title{
PPBP Gene Product
}

National Cancer Institute

\section{Source}

National Cancer Institute. PPBP Gene Product. NCI Thesaurus. Code C105903.

A protein encoded by the PPBP gene. 